\title{
Faktor-faktor yang mempengaruhi kepatuhan diet pasien hemodialisis
}

Factors that affect dietary compliance of the hemodialysis patients

\section{Fery Lusviana Widiany}

Program Studi S-1 Ilmu Gizi, Fakultas Ilmu Kesehatan Universitas Respati Yogyakarta

\begin{abstract}
Background: Riskesdas 2013 data shows the prevalence of chronic kidney disease in Central Java and Yogyakarta 0.3\%, which is higher than the average prevalence across Indonesia which is only $0.2 \%$. The results of the author's study previously showed that the intake of energy, protein, sodium hemodialysis patients on average are not sufficient, while the average fluid intake exceeds the dietary recommendation. There are several factors that can affect dietary compliance of the hemodialysis patients, such as knowledge, family support, attitudes, and behavior. Objective: To examine the factors that affect dietary compliance of the hemodialysis patients. Method: This is an observational study with cross-sectional design, conducted in the hemodialysis unit of Dr. Soeradji Tirtonegoro Hospital, Klaten on March - October 2016, involving 60 respondents. The dependent variable is dietary compliance, while the independent variables are knowledge, family support, attitudes, and behavior. Data were analyzed using univariate and bivariate with Chi-Square test. Results: Chi-Square test results of knowledge with dietary compliance showed the $p$-value $=0.027$; family support with dietary compliance showed the $p$-value $=0.045$; attitude with dietary compliance showed the $p$-value $=0.045$; and behavior with dietary compliance showed the p-value $=0.002$. Conclusion: Knowledge, family support, attitude, and behavior affect dietary compliance of the hemodialysis patients.
\end{abstract}

KEY WORDS: attitude; behavior; diet compliance; family support; hemodialysis patients; knowledge

\begin{abstract}
ABSTRAK
Latar belakang: Data Riskesdas 2013 menunjukkan prevalensi penyakit ginjal kronik di Jawa Tengah dan DIY sebesar 0,3\% yang lebih tinggi dibandingkan prevalensi rata-rata seluruh Indonesia yang hanya $0,2 \%$. Hasil penelitian penulis sebelumnya menunjukkan bahwa asupan energi, protein, dan natrium pasien hemodialisis rata-rata tidak mencukupi kebutuhan sedangkan asupan cairan rata-rata melebihi aturan diet yang diberikan. Terdapat beberapa faktor yang diduga dapat mempengaruhi kepatuhan diet pasien hemodialisis, diantaranya adalah pengetahuan, dukungan keluarga, sikap, dan perilaku pasien. Tujuan: Mengkaji faktor-faktor yang mempengaruhi kepatuhan diet pasien hemodialisis. Metode: Penelitian observasional dengan rancangan cross-sectional ini dilaksanakan di Unit Hemodialisis RSUP Dr. Soeradji Tirtonegoro Klaten pada bulan Maret - Oktober 2016 dengan melibatkan 60 responden. Variabel dependen adalah kepatuhan diet dan variabel independen adalah pengetahuan, dukungan keluarga, sikap, dan perilaku. Data dianalisis univariat dan bivariat dengan uji Chi-Square. Hasil: Analisis menunjukkan hasil yang bermakna antara pengetahuan dengan kepatuhan diet $(\mathrm{p}=0,027)$; dukungan keluarga dengan kepatuhan diet $(\mathrm{p}=0,045)$; sikap dengan kepatuhan $\operatorname{diet}(\mathrm{p}=0,045)$; dan perilaku dengan kepatuhan diet $(\mathrm{p}=0,002)$. Simpulan: Pengetahuan, dukungan keluarga, sikap, dan perilaku mempengaruhi kepatuhan diet pasien hemodialisis.
\end{abstract}

KATA KUNCI: sikap; perilaku; kepatuhan diet; dukungan keluarga; pasien hemodialisis; pengetahuan

\section{PENDAHULUAN}

Penyakit ginjal kronik (PGK) merupakan penyakit degeneratif yang menduduki peringkat 12 tertinggi penyebab angka kematian terbesar di dunia. Jumlah penderita PGK diperkirakan terus mengalami peningkatan. Saat ini, terdapat satu juta penduduk dunia yang sedang menjalani terapi pengganti ginjal (dialisis) dan angka ini terus bertambah sehingga diperkirakan pada tahun 2010 terdapat dua juta orang yang menjalani dialisis (1).

Korespondensi: Fery Lusviana Widiany, Program Studi S-1 Ilmu Gizi, Fakultas Ilmu Kesehatan Universitas Respati Yogyakarta, Jl. Raya Tajem KM 1,5 Maguwoharjo, Depok, Sleman, Yogyakarta, Indonesia, Telp. 0274-4437888, e-mail: fer_luzz_wee@yahoo.com 
Data Riskesdas 2013 menyebutkan prevalensi penderita PGK di Provinsi Daerah Istimewa Yogyakarta (DIY) dan Jawa Tengah masing-masing sebesar $0,3 \%$ sehingga dinyatakan lebih tinggi dibandingkan dengan prevalensi rata-rata seluruh Indonesia yaitu sebesar 0,2\% (2). Di RSUP Dr. Soeradji Tirtonegoro Klaten yang merupakan rumah sakit besar tipe $B$, jumlah pasien hemodialisisnya pun dari tahun ke tahun mengalami peningkatan yang cukup signifikan, yaitu meningkat 25,3\% dari tahun 2010 ke tahun 2011.

Penyakit ginjal kronik adalah keadaan fungsi ginjal yang mengalami penurunan cukup berat dan terjadi perlahan-lahan (menahun) yang disebabkan oleh berbagai penyakit ginjal, bersifat progresif, dan umumnya tidak dapat pulih. Kondisi ini menyebabkan ginjal gagal untuk mempertahankan metabolisme serta keseimbangan cairan dan elektrolit (3) sehingga diperlukan terapi pengganti berupa hemodialisis. Hemodialisis pada umumnya dilakukan rutin 2 kali setiap minggu dengan waktu kurang lebih 5 jam setiap menjalani hemodialisis, tetapi ada juga yang menjalani hemodialisis 3 kali setiap minggunya dengan waktu 4 jam (4).

Salah satu masalah besar yang berkontribusi pada kegagalan hemodialisis adalah masalah kepatuhan klien. Secara umum, kepatuhan (adherence) didefinisikan sebagai tingkatan perilaku seseorang yang mendapatkan pengobatan, mengikuti diet, dan melaksanakan perubahan gaya hidup sesuai dengan rekomendasi pelayanan kesehatan (5). Kepatuhan pasien yang rendah menjadi masalah besar di institusi pelayanan kesehatan yang diakibatkan oleh komponen pengobatan medis dan kondisi sosial ekonomi pasien, khususnya pada pasien PGK (6). Selain itu, ketidakpatuhan pasien yang menjalani hemodialisis dapat berdampak pada timbulnya malnutrisi.

Pasien yang menjalani hemodialisis rutin akan mengalami malnutrisi asupan protein yang tidak adekuat, rendahnya kadar albumin dalam darah, gangguan gastrointestinal seperti rasa mual, muntah, dan menurunnya nafsu makan (4). Selain itu, pasien hemodialisis rutin juga bermasalah dalam hal retensi garam dan cairan, retensi pospat, hiperparatiroidisme sekunder, hipertensi, anemia kronik, hiperlipidemia, dan penyakit jantung (6). Oleh karena itu, kepatuhan diet sangat diperlukan untuk mengatasi masalah malnutrisi pada pasien hemodialisis tersebut. Kepatuhan berarti pasien harus meluangkan waktu dalam menjalani pengobatan yang dibutuhkan seperti dalam pengaturan diet maupun cairan (7).

Penelitian di RSUP Dr. Soeradji Tirtonegoro Klaten pada tahun 2015 menyebutkan bahwa ternyata asupan energi, protein, dan natrium pasien hemodialisis rata-rata tidak mencukupi kebutuhan sedangkan asupan cairan rata-rata melebihi aturan diet yang diberikan. Kenaikan berat badan pasien hemodialisis rata-rata melebihi kenaikan berat badan interdialisis ideal yang seharusnya hanya $1,5 \mathrm{~kg}$ sehingga dapat diartikan tingkat keberhasilan diet hemodialisis pasien masih kurang (8).

Kepatuhan pasien dapat dipengaruhi oleh beberapa faktor. Penelitian ini dilakukan untuk mengkaji faktorfaktor yang mempengaruhi kepatuhan diet pasien hemodialisis. Penelitian ini mengulas lebih banyak variabel dibandingkan penelitian-penelitian sebelumnya, yakni empat variabel independen (pengetahuan, dukungan keluarga, sikap, perilaku) dan satu variabel dependen (kepatuhan diet). Dalam penelitian ini, juga dikaji faktor yang paling dominan mempengaruhi kepatuhan diet pasien hemodialisis.

\section{BAHAN DAN METODE}

Penelitian berjenis observasional dengan rancangan cross-sectional ini dilaksanakan di Unit Hemodialisis RSUP Dr. Soeradji Tirtonegoro Klaten pada bulan Maret-Oktober 2016. Populasi penelitian ini adalah semua pasien yang menjalani hemodialisis rutin di unit hemodialisis. Sampel penelitian diambil dengan teknik purposive sampling. Berdasarkan perhitungan sampel dengan standar eror ( $\alpha$ ) sebesar $10 \%$, diperoleh besar sampel minimal untuk penelitian ini adalah 60 orang. Kriteria inklusi penelitian ini meliputi usia lebih dari 18 tahun, menjalani hemodialisis rutin 2 kali per minggu, bersedia menjadi responden dan mengikuti prosedur penelitian, dapat berkomunikasi dengan baik, bisa membaca dan menulis, serta pernah mendapatkan konsultasi gizi dari ahli gizi rumah sakit mengenai diet hemodialisis.

Penelitian ini menggunakan empat variabel independen yaitu pengetahuan, dukungan keluarga, 
sikap, perilaku, serta variabel dependen yaitu kepatuhan diet. Pengetahuan didefinisikan sebagai segala sesuatu yang diketahui oleh pasien mengenai PGK dengan hemodialisis dan terapi dietnya. Dukungan keluarga adalah dukungan-dukungan yang diberikan oleh keluarga yang tinggal bersama pasien yang diperoleh dari hasil pengisian kuesioner dengan metode wawancara. Keluarga dalam penelitian ini adalah keluarga inti (orang tua, anak, suami/istri). Sikap adalah tanggapan responden yang mendukung atau menolak hal-hal yang dianjurkan dalam diet hemodialisis yang pernah diberikan oleh ahli gizi rumah sakit. Perilaku adalah respon seorang pasien berupa tindakan langsung yang berkaitan dengan diet hemodialisis yang pernah diberikan oleh ahli gizi rumah sakit. Adapun kepatuhan diet didefinisikan sebagai kepatuhan responden terhadap penatalaksanaan diet hemodialisis yang diberikan oleh ahli gizi rumah sakit. Kepatuhan diet didasarkan pada hasil skor pengisian kuesioner kepatuhan diet yang berisi 15 item pernyataan mengenai kebiasaan responden dalam menerapkan diet hemodialisis.

Semua data dalam penelitian ini diambil dengan cara wawancara langsung kepada responden menggunakan kuesioner. Kuesioner yang digunakan untuk penelitian ini dirancang sendiri oleh peneliti dengan terlebih dahulu melakukan uji validitas kuesioner dan memodifikasinya untuk memenuhi objektivitas penelitian. Peneliti juga melakukan uji expert terhadap kuesioner dengan cara mendistribusikannya untuk diulas oleh tiga orang dosen Program Studi Ilmu Gizi Universitas Respati Yogyakarta yang berkonsentrasi dalam bidang gizi klinik. Uji expert dilakukan untuk mengulas kesesuaian isi agar diperoleh validitas kuesioner dan hasil uji expert ini kemudian digunakan sebagai landasan untuk memodifikasi kuesioner tersebut. Setelah dimodifikasi, kuesioner diujicobakan kepada pasien hemodialisis di RSUD Panembahan Senopati Bantul terlebih dahulu untuk menentukan apakah pertanyaan-pertanyaan yang tertuang dalam kuesioner dapat dengan mudah dimengerti oleh responden.

Setelah penandatanganan informed consent, responden diwawancara untuk pengisian kuesioner identitas dan karakteristik responden, serta kuesioner pengetahuan, dukungan keluarga, sikap, perilaku, dan kepatuhan diet. Pengisian semua kuesioner membutuhkan waktu sekitar 15 - 20 menit. Hasil pengisian kuesioner tersebut kemudian dinilai dengan skor dalam bentuk persentase (\%) dan dikategorikan menjadi baik ( $\geq 75 \%$ ) dan tidak baik $(<75 \%)$ untuk variabel pengetahuan, dukungan keluarga, sikap, perilaku, serta kategori patuh $(\geq 75 \%)$ dan tidak patuh (skor $<75 \%)$ untuk variabel kepatuhan diet.

Data yang diperoleh diolah dan dianalisis secara univariat untuk melihat distribusi frekuensi setiap variabel, dilanjutkan analisis bivariat dengan uji ChiSquare untuk mengetahui hubungan variabel independen dan dependen, serta analisis multivariat dengan uji regresi logistik ganda untuk mengetahui faktor yang paling dominan mempengaruhi variabel dependen. Penelitian ini telah memperoleh Ethical Clearance dari Komisi Etik Penelitian Kesehatan Fakultas Ilmu Kesehatan Universitas Respati Yogyakarta No. 199.4/FIKES/PL/ IV/2016.

\section{HASIL}

Responden penelitian ini diperoleh sebanyak 60 orang yang diambil dengan teknik purposive sampling, yang diambil dari pasien shift pagi dan siang. Pengambilan sampel hanya shift pagi dan siang dimaksudkan agar responden memiliki karakteristik yang sama, termasuk perolehan materi konsultasi dari ahli gizi rumah sakit. Semua pasien telah memperoleh konsultasi gizi mengenai diet hemodialisis sebelumnya.

Tabel 1. Distribusi frekuensi responden berdasarkan pengetahuan, dukungan keluarga, sikap, perilaku, dan kepatuhan diet

\begin{tabular}{llcc}
\hline Variabel & Kategori & $\begin{array}{c}\text { Jumlah } \\
\text { (n) }\end{array}$ & $\begin{array}{c}\text { Persentase } \\
\text { (\%) }\end{array}$ \\
\hline Pengetahuan & Baik & 42 & 70 \\
& Tidak baik & 18 & 30 \\
Dukungan keluarga & Baik & 52 & 87 \\
& Tidak baik & 8 & 13 \\
Sikap & Baik & 52 & 87 \\
Perilaku & Tidak baik & 8 & 13 \\
& Baik & 51 & 85 \\
Kepatuhan diet & Tidak baik & 9 & 15 \\
& Patuh & 42 & 70 \\
& Tidak patuh & 18 & 30 \\
\hline
\end{tabular}


Fery Lusviana Widiany: Faktor-faktor yang mempengaruhi kepatuhan diet pasien hemodialisis

Tabel 2. Hasil analisis bivariat pengaruh masing-masing faktor (pengetahuan, dukungan keluarga, sikap, dan perilaku) terhadap kepatuhan diet

\begin{tabular}{|c|c|c|c|c|c|c|}
\hline \multirow[b]{2}{*}{ Variabel } & \multirow[b]{2}{*}{ Kategori } & \multicolumn{2}{|c|}{ Kepatuhan diet } & \multirow{2}{*}{$\begin{array}{l}\text { Total } \\
\text { n (\%) }\end{array}$} & \multirow[b]{2}{*}{$\mathbf{p}$} & \multirow[b]{2}{*}{ RR (95\% CI) } \\
\hline & & $\begin{array}{c}\text { Tidak patuh }^{3} \\
\text { n (\%) } \\
\end{array}$ & $\begin{array}{l}\text { Patuh }^{4} \\
\text { n (\%) } \\
\end{array}$ & & & \\
\hline \multirow[t]{3}{*}{ Pengetahuan } & Tidak baik $^{1}$ & $9(50)$ & $9(50)$ & $18(100)$ & 0,027 & 3,667 \\
\hline & Baik $^{2}$ & $9(21)$ & $33(79)$ & $42(100)$ & & $(1,125-11,955)$ \\
\hline & Total & $18(30)$ & $42(70)$ & $60(100)$ & & \\
\hline Dukungan & Tidak baik ${ }^{1}$ & $5(62)$ & $3(38)$ & $8(100)$ & 0,045 & 5,000 \\
\hline \multirow[t]{2}{*}{ keluarga } & Baik $^{2}$ & $13(25)$ & $39(75)$ & $52(100)$ & & $(1,048-23,864)$ \\
\hline & Total & $18(30)$ & $42(70)$ & $60(100)$ & & \\
\hline \multirow[t]{3}{*}{ Sikap } & Tidak baik ${ }^{1}$ & $5(62)$ & $3(38)$ & $8(100)$ & 0,045 & 5,000 \\
\hline & Baik $^{2}$ & $13(25)$ & $39(75)$ & $52(100)$ & & $(1,048-23,864)$ \\
\hline & Total & $18(30)$ & $42(70)$ & $60(100)$ & & \\
\hline \multirow[t]{3}{*}{ Perilaku } & Tidak baik $^{1}$ & $7(78)$ & $2(22)$ & $9(100)$ & 0,002 & 12,727 \\
\hline & Baik $^{2}$ & $11(22)$ & $40(78)$ & $51(100)$ & & $(2,308-70,177)$ \\
\hline & Total & $18(30)$ & $42(70)$ & $60(100)$ & & \\
\hline
\end{tabular}

${ }^{1}$ Tidak baik $=$ skor perolehan kuesioner $\geq 75 \% ;{ }^{2}$ Baik $=$ skor perolehan kuesioner $<75 \% ;{ }^{3}$ Tidak patuh $=$ skor perolehan kuesioner kepatuhan diet $\geq 75 \%$; ${ }^{4}$ Patuh $=$ skor perolehan kuesioner kepatuhan diet $<75 \%$

Tabel 3. Hasil analisis multivariat dengan uji regresi logistik ganda

\begin{tabular}{|c|c|c|c|c|c|c|c|}
\hline \multirow[b]{2}{*}{ Variabel } & \multirow[b]{2}{*}{ Kategori } & \multicolumn{2}{|c|}{ Kepatuhan diet } & \multirow{2}{*}{$\begin{array}{l}\text { Total } \\
\text { n (\%) }\end{array}$} & \multirow[b]{2}{*}{ B } & \multirow[b]{2}{*}{ SE } & \multirow[b]{2}{*}{$\mathbf{p}$} \\
\hline & & $\begin{array}{c}\text { Tidak patuh } \\
\text { n (\%) }\end{array}$ & $\begin{array}{l}\text { Patuh } \\
\text { n (\%) }\end{array}$ & & & & \\
\hline \multirow[t]{2}{*}{ Pengetahuan } & Tidak baik & $9(50)$ & $9(50)$ & $18(100)$ & 1,607 & 0,725 & 0,022 \\
\hline & Baik & $9(21)$ & $33(79)$ & $42(100)$ & & & \\
\hline Dukungan & Tidak baik & $5(62)$ & $3(38)$ & $8(100)$ & 1,743 & 0,943 & 0,061 \\
\hline Keluarga & Baik & $13(25)$ & $39(75)$ & $52(100)$ & & & \\
\hline \multirow[t]{2}{*}{ Sikap } & Tidak baik & $5(62)$ & $3(38)$ & $8(100)$ & $-16,467$ & 0,993 & 0,419 \\
\hline & Baik & $13(25)$ & $39(75)$ & $52(100)$ & & & \\
\hline \multirow[t]{2}{*}{ Perilaku } & Tidak baik & $7(78)$ & $2(22)$ & $9(100)$ & 18,996 & 0,000 & 0,024 \\
\hline & Baik & $11(22)$ & $40(78)$ & $51(100)$ & & & \\
\hline
\end{tabular}

Karakteristik usia responden dibagi menjadi dewasa (yang berusia dibawah 60 tahun) dan lanjut usia (yang berusia $\geq 60$ tahun). Hasil penelitian menunjukkan bahwa responden dewasa lebih banyak (70\%) daripada lansia (30\%). Responden perempuan lebih banyak (52\%) daripada laki-laki (48\%).

Tabel 1 menunjukkan hasil bahwa responden dengan pengetahuan baik lebih banyak daripada responden dengan pengetahuan tidak baik. Responden yang memperoleh dukungan baik dari keluarga jumlahnya lebih banyak daripada responden yang tidak memperoleh dukungan baik dari keluarganya. Responden yang bersikap baik (memberikan tanggapan positif terhadap diet hemodialisis yang diberikan oleh ahli gizi rumah sakit) lebih banyak daripada responden yang bersikap tidak baik. Responden yang berperilaku baik (melakukan tindakan baik berkaitan dengan diet hemodialisis yang diberikan oleh ahli gizi rumah sakit) lebih banyak daripada responden yang berperilaku tidak baik. Serta dilihat dari kepatuhan dietnya, responden yang patuh terhadap diet yang diberikan jumlahnya lebih banyak daripada responden yang tidak patuh.

Hasil analisis statistik dengan uji Chi-square, diperoleh hasil bahwa faktor pengetahuan mempengaruhi kepatuhan diet secara signifikan $(p=0,027)$. Responden dengan pengetahuan baik memiliki kemungkinan 3,7 kali lebih besar untuk patuh terhadap diet hemodialisis yang diberikan oleh ahli gizi rumah sakit dibandingkan responden yang berpengetahuan tidak baik. Hasil uji Fisher's Exact menunjukkan faktor dukungan keluarga 
dan sikap mempengaruhi kepatuhan diet $(\mathrm{p}=0,045)$, demikian pula faktor perilaku mempengaruhi kepatuhan $\operatorname{diet}(\mathrm{p}=0,002)$. Responden yang memperoleh dukungan baik dari keluarganya dan mampu memberikan tanggapan positif terhadap diet hemodialisis yang diberikan oleh ahli gizi rumah sakit memiliki kemungkinan 5 kali lebih besar untuk patuh terhadap diet yang diberikan dibandingkan responden yang tidak memperoleh dukungan baik dari keluarganya dan tidak memberikan tanggapan positif terhadap diet hemodialisis yang diberikan oleh ahli gizi rumah sakit. Responden yang berperilaku baik (melakukan tindakan baik berkaitan dengan diet hemodialisis yang diberikan oleh ahli gizi rumah sakit) memiliki kemungkinan 12,7 kali lebih besar untuk patuh terhadap diet hemodialisis yang diberikan oleh ahli gizi rumah sakit dibandingkan responden yang tidak berperilaku baik (Tabel 2).

Tabel 3 menunjukkan bahwa berdasarkan hasil analisis multivariat dengan uji regresi logistik ganda, diketahui bahwa perilaku merupakan faktor yang paling dominan mempengaruhi kepatuhan diet responden $(\mathrm{p}=0,024 ; \mathrm{B}=18,996)$. Faktor dukungan keluarga dan sikap justru menjadi tidak bermakna pengaruhnya terhadap kepatuhan diet $(\mathrm{p}=0,061 ; \mathrm{B}=1,743$ untuk dukungan keluarga dan $\mathrm{p}=0,419 ; \mathrm{B}=-16,467$ untuk sikap).

\section{BAHASAN}

Responden penelitian ini didominasi oleh perempuan (yang tidak berbeda signifikan jumlahnya dengan responden laki-laki) dan berusia dewasa $(<60$ tahun). Usia merupakan salah satu faktor yang dapat mempengaruhi perilaku seseorang sedangkan dalam kepatuhan, usia termasuk dalam salah satu komponen dari faktor pasien yang mampu mempengaruhi kepatuhan seseorang (9). Namun, pada usia yang lebih tua belum tentu akan lebih mengetahui apabila tidak ditunjang dengan pengetahuan dan pengalaman yang pernah dialami. Sementara pada penderita yang tidak patuh dipandang sebagai seorang yang lalai, mengalami depresi, ansietas, sangat memperhatikan kecemasannya, dan memiliki keyakinan ego yang lebih lemah yang ditandai dengan kekurangan dalam hal pengendalian diri sendiri dan kurangnya penguasaan terhadap lingkungan, dan bukan hanya karena pengaruh dari usia penderita (10). Pasien berusia muda umumnya kurang berpengetahuan dan lebih patuh, memiliki nafsu makan yang lebih rendah dan kematian lebih tinggi daripada pasien berusia tua (11). Pada penelitian ini, responden didominasi oleh orang dewasa dan lebih banyak yang patuh dibandingkan yang tidak patuh.

Hasil penelitian sebelumnya di Unit Hemodialisis RSUP Dr. Soeradi Tirtonegoro Klaten menunjukkan bahwa rerata asupan energi, protein, dan natrium pasien kurang apabila dibandingkan dengan kebutuhan. Rerata asupan energi hanya terpenuhi $16,6 \mathrm{kcal} / \mathrm{kg}$ BB dan rerata asupan protein sebesar $0,6 \mathrm{~g} / \mathrm{kg} \mathrm{BB}$. Hal ini dapat menyebabkan risiko penurunan status gizi pada pasien. Asupan natrium juga tergolong kurang (rerata hanya $277,5 \mathrm{mg} /$ hari) yang berisiko terjadinya renjatan atau syok pada pasien saat dilakukannya tindakan hemodialisis. Sementara itu, asupan cairan masih tergolong cukup tinggi, yaitu sebesar 814,4 ml/hari (8).

Pada pasien PGK yang menjalani hemodialisis rutin sering mengalami kelebihan volume cairan dalam tubuh, hal ini disebabkan penurunan fungsi ginjal dalam mengekresikan cairan (10). Belum adanya goal standar untuk pengukuran kepatuhan diet pasien hemodialisis sehingga parameter kepatuhan harus dapat terukur dengan mudah dan terverifikasi, mudah diinterpretasikan, dan akurat (12). Pengukuran kepatuhan diet dalam penelitian ini menggunakan kuesioner kepatuhan diet yang telah teruji validitasnya.

Hasil penelitian ini sejalan dengan hasil penelitian sebelumnya bahwa sebagian besar responden memperoleh dukungan sosial yang baik dari keluarga $(44,2 \%)$ dan patuh terhadap diet hemodialisis yang diberikan $(57,7 \%)$ (13). Tingkat pendidikan pasien berhubungan dengan kepatuhan dalam pembatasan cairan. Kepatuhan diet dapat meningkat dengan pemberian konseling gizi dan edukasi dapat memotivasi pasien untuk berubah dan patuh terhadap rekomendasi diet (14).

Hasil analisis penelitian ini menunjukkan bahwa pengetahuan, dukungan keluarga, sikap, dan perilaku berhubungan signifikan dengan kepatuhan diet pasien. PGK mempengaruhi pemilihan makanan dan kebiasaan makan pasien. Pengetahuan tentang preferensi ini akan 
membantu ahli gizi merencanakan diet yang memadai dan menyenangkan untuk pasien tersebut. Intervensi yang diberikan berupa edukasi gizi dapat meningkatkan pengetahuan pasien, tetapi tidak dengan perubahan hasil laboratoriumnya (15). Pemberian konseling gizi yang disertai dengan pemberian leaflet berpengaruh signifikan terhadap asupan zat gizi (lemak, natrium, kalium, dan magnesium), baik penurunan asupan lemak dan natrium, maupun peningkatan asupan kalium dan magnesium (16).

Pengetahuan kognitif merupakan domain yang sangat penting untuk terbentuknya suatu tindakan, perilaku yang didasarkan pengetahuan akan lebih langgeng daripada perilaku yang tidak didasarkan oleh pengetahuan (9). Pasien menggunakan informasi dan keterampilan untuk membuat keputusan tentang kapan waktu yang tepat untuk dapat melaksanakan intervensi tertentu. Di luar tindakan hemodialisis, pasien diharapkan dapat mengikuti secara keseluruhan sesuai dengan yang telah diresepkan, baik obat, diet khusus, keterbatasan cairan, dan perawatan vaskular (17).

Pengetahuan pasien dapat meningkat dengan pemberian konseling gizi. Proses konseling pada pasien yang menjalani hemodialisis dapat dilakukan minimal selama enam kali kunjungan, bila masih dirasakan perlu, maka dapat dilakukan kunjungan ulang lagi (18). Waktu ideal untuk melakukan konseling adalah selama 30-60 menit. Proses konseling yang diberikan mempunyai fungsi antara lain sebagai fungsi pencegahan, fungsi adaptasi, fungsi perbaikan, dan fungsi pengembangan terhadap masalah kesehatan yang dialami (19). Pemberian konseling gizi mampu membuat pasien mengetahui, menentukan, melaksanakan, dan menaati diet hemodialisis sehari-hari. Waktu pengambilan data dalam penelitian ini hanya dilakukan pada shift pagi dan siang saja sehingga perolehan materi melalui proses konseling gizi oleh semua responden dapat diasumsikan sama dan terkendali.

Sejalan pula dengan hasil penelitian di Iran yang menyebutkan bahwa terdapat hubungan yang signifikan antara dukungan sosial dengan kepatuhan diet pasien hemodialisis (20). Keluarga berfungsi sebagai sistem pendukung bagi anggotanya. Anggota keluarga juga memandang bahwa orang yang bersifat mendukung selalu siap memberikan pertolongan dan bantuan jka diperlukan. Dukungan keluarga adalah sikap, tindakan, dan penerimaan keluarga terhadap penderita yang sakit (9). Dukungan keluarga yang berupa perhatian, emosi, informasi, nasehat, motivasi maupun pemahaman yang diberikan oleh sekelompok anggota keluarga terhadap anggota keluarga yang lain sangatlah dibutuhkan. Dukungan keluarga sangat diperlukan untuk keberhasilan terapi agar dapat mempertahankan status kesehatan keluarga. Keberhasilan diet hemodialisis dipengaruhi oleh kepatuhan seseorang dalam menjalankan diet yang dianjurkan. Tanggung jawab dalam pengaturan makanan akan dipegang oleh pasien dan keluarganya saat berada di rumah. Dengan demikian, sangat perlu bagi seorang pasien dan keluarga untuk mengetahui dan memahami pengaturan makanan bagi pasien (21).

Dukungan keluarga juga menjadi faktor penting yang mempengaruhi kepatuhan, diharapkan anggota keluarga mampu untuk meningkatkan dukungannya sehingga ketidaktaatan terhadap program diet yang akan dilaksanakan lebih dapat dikurangi. Riset telah menunjukkan bahwa jika kerjasama anggota keluarga sudah terjalin, ketaatan terhadap program-program medis yang salah satunya adalah program diet menjadi lebih tinggi (21). Responden yang memiliki dukungan keluarga yang baik dan patuh dalam menjalankan diet disebabkan oleh faktor dukungan keluarga yang baik. Hal ini sangat berpengaruh dalam menentukan keyakinan dan nilai kesehatan serta dapat menentukan program pengobatan yang diterima. Selain itu, dukungan yang diberikan oleh keluarga kepada pasien sangat mempengaruhi proses penyembuhan lewat pemberian perhatian, rasa dicintai, dan dihargai yang dapat menjadi dukungan yang besar untuk patuh dalam menjalankan diet. Responden yang memiliki dukungan keluarga yang kurang dan tidak patuh menjalankan diet disebabkan oleh tingkat pendidikan yang kurang. Tingkat pendidikan mempengaruhi seseorang untuk mempertahankan hidup yang sehat yaitu dengan patuh menjalankan diet pada pasien PGK (9).

Selain pengetahuan dan dukungan keluarga, sikap dan perilaku pasien hemodialisis juga berhubungan dengan kepatuhan dietnya. Hasil penelitian ini menunjukkan jumlah responden dengan pengetahuan, sikap, dan perilaku baik lebih banyak dibandingkan yang tidak baik. 
Demikian pula jumlah responden yang patuh terhadap diet lebih banyak dibandingkan yang tidak patuh. Kesadaran pasien hemodialisis untuk melaksanakan diet yang diberikan berhubungan signifikan dengan kepatuhan diet pasien (22). Sikap pasien merupakan faktor predisposisi untuk terjadinya perilaku, maka pasien PGK yang menjalani terapi hemodialisis yang merasa terancam kesehatannya oleh penyakit yang diderita dan kepercayaannya terhadap program diet hemodialisis yang diberikan akan memunculkan sikap baik sehingga cenderung untuk berperilaku patuh (23).

Lebih lanjut, perilaku seseorang dapat terbentuk yang dipengaruhi oleh faktor eksternal (lingkungan fisik dan non-fisik dalam bentuk sosial, budaya, ekonomi, dan politik) dan faktor internal (perhatian, pengamatan, persepsi, motivasi, fantasi, dan sugesti). Pengetahuan merupakan salah satu faktor yang diharapkan dapat berpengaruh positif terhadap perilaku seseorang. Perilaku akan bersifat langgeng (long lasting) apabila didasari oleh pengetahuan, kesadaran, dan sikap yang positif. Sebaliknya, apabila perilaku itu tidak didasari oleh pengetahuan dan kesadaran maka tidak akan berlangsung lama (21).

\section{SIMPULAN DAN SARAN}

Pengetahuan, dukungan keluarga, sikap, dan perilaku mempengaruhi kepatuhan diet pasien hemodialisis. Berdasarkan kesimpulan tersebut, maka disarankan kepada pihak rumah sakit untuk melakukan monitoring secara berkesinambungan terhadap kepatuhan diet pasien. Perlu dilakukan penelitian lebih lanjut mengenai faktor-faktor lain yang mempengaruhi kepatuhan diet pasien hemodialisis.

\section{Pernyataan konflik kepentingan}

Tidak ada konflik kepentingan dalam penelitian ini.

\section{RUJUKAN}

1. Desita. Pengaruh dukungan keluarga terhadap peningkatan kualitas hidup pasien gagal ginjal kronik yang menjalani hemodialisa di RSUP HAM Medan [Tesis]. Medan: Universitas Sumatera Utara; 2010.
2. Badan Penelitian dan Pengembangan Kesehatan Kementerian Kesehatan RI. Riset kesehatan dasar. Jakarta: Kementerian Kesehatan RI; 2013.

3. Muttaqin A, Kumala S. Gangguan gastrointestinal: aplikasi asuhan keperawatan medical bedah. Jakarta: Salemba Pustaka; 2011.

4. Suhardjono. Buku ajar ilmu penyakit dalam jilid 2 edisi 3. Jakarta: Balai Penerbit FKUI; 2001.

5. WHO. Adherence long-term therapies. Evidence for action [series online] 2003 [cited 19 Desember 2016]. Available from: URL: http://www.emro.who.int/

6. Kammerer J, Garry G, Hartigan M, Carter B, Erlich L. Adherence in patients on dialysis: strategies for success. Nephrology Nursing Journal [series online] 2007;34(5) [cited 19 Desember 2016]. Available from: URL: http:// www.ncbi.nlm.nih.gov

7. Panjaitan EM, Siregar MA, Sudaryati E. Gambaran kepatuhan diet dan dukungan keluarga pada penderita gagal ginjal kronik yang menjalani hemodialisa rawat jalan di RSU Haji Medan Tahun 2014 [Skripsi]. Medan: Universitas Sumatera Utara; 2014.

8. Widiany FL. Kajian kepatuhan diet pasien hemodialisis ditinjau dari asupan zat gizi dan kenaikan berat badan interdialisis. Medika Respati Suplemen 2017;12:137-42.

9. Sumigar G, Rompas S, Pondaag L. Hubungan dukungan keluarga dengan kepatuhan diet pada pasien gagal ginjal kronik di Irina C2 dan C4 RSUP Prof. Dr. R. D. Kandou Manado. ejournal Keperawatan (e-Kep) [series online] 2015 [cited 19 Desember 2016];3(1). Available from: URL: http:// ejournal.unsrat.ac.id/index.php/jkp/article/view/6686

10. Kamaluddin R, Rahayu E. Analisis faktor-faktor yang mempengaruhi kepatuhan asupan cairan pada pasien gagal ginjal kronik dengan hemodialisis di RSUD Prof. Dr. Margono Soekarjo Purwokerto. Jurnal Keperawatan Soedirman (The Soedirman Journal of Nursing) [series online] 2009;4(1) [cited 19 Desember 2016]. Available from: URL: http://jks.fikes.unsoed.ac.id/index.php/jks/ article/view/218

11. Park KA, Choi-Kwon S, Sim Y, Kim SB. Comparison of dietary compliance and dietary knowledge between older and younger korean hemodialysis patients. Journal of Renal Nutrition 2008;18(5):415-23.

12. Kaveh K, Kimmel PL. Compliance in hemodialysis patients: multidimensional measures in search of a gold standard. American Journal of Kidney Diseases 2001;37(2):244-66.

13. Budiono A. Analisis faktor dukungan sosial terhadap kepatuhan dalam menjalani hemodialisis rutin di Unit Hemodialisa RSUD Kota Salatiga [Skripsi]. Surakarta: Stikes Kusuma Husada; 2016. 
14. Rambod M, Peyravi H, Shokrpour N, Sareban MT. Dietary and fluid adherence in Iranian hemodialysis patients. The Health Care Manager 2010;29(4):359-64.

15. Ford JC, Pope JF, Hunt AE, Gerald B. The effect of diet education on the laboratory values and knowledge of hemodialysis patients with hyperphosphatemia. Journal of Renal Nutrition 2004;14(1):36-44.

16. Suwarni, Asdie HAH, Astuti H. Konseling gizi dan pengaruhnya terhadap asupan zat gizi dan tekanan darah pada pasien hipertensi rawat jalan di Rumah Sakit Umum Daerah Provinsi Sulawesi Tenggara. Jurnal Gizi Klinik Indonesia 2009;6(1):21-28.

17. Richard CJ. Self-care management in adults undergoing hemodialysis. Nephrology Nursing Journal [series online] 2006;33(4). [cited 19 Desember 2016]. Available from: URL: http://www.ncbi.nlm.nih.gov/pubmed/17001996

18. Cornelia, Sumedi E, Anwar I, Ramayulis R, Iwaningsih S, Kresnawan T. Konseling gizi. Jakarta: Penebar Plus; 2013.
19. Mundakir. Komunikasi keperawatan : aplikasi dalam pelayanan. Yogyakarta: Graha Ilmu; 2006.

20. Ahrari S, Moshki M, Bahrami M. The relationship between social support and adherence of dietary and fluids restrictions among hemodialysis patients in Iran. Journal of Caring Sciences 2014;3(1):11-19.

21. Pratiwi Y, Endang N. Hubungan antara dukungan keluarga dengan kepatuhan diit pada pasien diabetes mellitus tipe 2 rawat jalan di RSUD dr. Soediran Mangun Sumars [series online] 2009 [cited 19 Desember 2016]. Available from: URL: http://publikasiilmiah.ums.ac.id/

22. John A, Alpert PT, Kawi J, Tandy R. The relationship between self-efficacy and fluid and dietary compliance in hemodialysis patients. Clinical Scholars Review 2013;6(2):98-104.

23. Mardjun F. Faktor yang berhubungan dengan kepatuhan pembatasan asupan cairan pada pasien gagal ginjal kronik di ruang hemodialisa RSUD Prof. Dr. H. Aloei Saboe Kota Gorontalo [Skripsi]. Gorontalo: Universitas Negeri Gorontalo; 2014. 